\title{
A Study for Locations of Accident Prone on Some Provincial Roads in the West Kalimantan Province
}

\author{
Slamet Widodo \\ Department of Civil Engineering, Faculty of Engineering, Universitas Tanjungpura, Jl. Prof. Dr. Hadari Nawawi, Pontianak \\ 78124, Indonesia \\ Corresponding Author: slametwidodo@ civil.untan.ac.id
}

\section{Article history}

Received: 12.01.2021

Revised: 22.03.2021

Accepted: 25.04.2021

DOI: $10.31629 /$ jit.v2i1.3208

\begin{abstract}
Nowadays more than one million people become victim in an accident on the roads. Some efforts have already been done to reduce globally the number accident. This paper is to show the condition of some provincial roads as location study in province of West Kalimantan regarding with description, characteristic, and the causes of accident. The results indicate that the human error take part dominantly around of $65 \%$ accident number, meanwhile vehicle condition and road environment contribute less than $5 \%$. The provincial road is dominated by the two-lane two-way facility. The finding shows the frontal collision type around of $42 \%$ on the accident number. Number of motor cycle dominate the type of vehicle on the road. It coincides with percentage of motor cycle significant involved at an accident around of $71 \%$. The frontal collision at location of study is more than twice compared to national data. Ratio number of accidents to length of road is located on the road segment from Ketapang area to Pesaguan and around of 0.884 each kilometer.
\end{abstract}

Keywords: provincial road; human error; collision; probability of accident

\section{Introduction}

Nowadays in the world, number of dead toll because of accident on the roads and/or highways is around 1.3 millions people and more than 25 millions of them became permanent disbility. The accident would be predicted as the fifth death in the world till 2030. Besides that, loss because of accident will take around 2 percent of product domestic bruto [1]. Based on classsification of road status that there are three categories namely state, provincial, city/regency. This paper will investigate and discuss some provincial roads in two regencies of West Kalimantan province. The provincial roads was chosen with some reasons like the longest road compared to state road and city/regency road [2], mainly located in rural area, and it was an important link in contributing economic growth of region.

Characteristic of accident victims in the world, firstly more than a half of accident victims has age between 15 and 44 years old. Secondly, more than 70 percent of victim has gender as man. The last one, number of victim (pedestrian, cyclist and motorist) is bigger in developing countries than developed countries. Furthermore, in developed countries the accident level each 100,000 inhabitant is between 11 and 15. Besides that in developing countries it is range 16 to 28 [1]. Potrait of accident victim in 
Indonesia is not big different compared to picture of global characteristic. Based on data in year of 2008 that more than a half of accident victim has range of age between 15 and 44 years old. More or less 77 percent of accident victim has gender as man [1]. Important information regarding with types of collision for non-toll roads in Indonesia as follows: 35 percent out of track, 19 percent front-rear, 20 percent frontal collision, 15 percent side collision, 8 percent of pedestrian as victim, and 3 percent simultaneous collision.

\section{Materials and Methods}

\subsection{Location Study}

There are four road segment as provincial road status chosen in this research which located on two regencies from 14 regencies in West Kalimantan province. The first is the road segment between Nanga Tayap and Manis Mata. The second is the road segment located between Ketapang and Kendawangan. The third, the road segment between Simpang Pelang and Batu Tajam. The fourth, the road segment between Teluk Batang and Simpang Siduk.

\subsection{Steps of Work}

\subsubsection{Preparation}

Before going to field for collecting primary data, it needs good preparation technically and/or mentally. The preparation consists of: collecting some literatures and rules, distributing job description, grabbing information, and forecasting some hitches/handicaps.

\subsubsection{Collecting Data}

For secondary data, mainly the accident data was collected from West Kalimantan Police Base which it was well collected by means of year by year. The accident data within 3 years $(2014,2015$, and 2016) is elaborated in the analysis step. But the accident data is also collected from local police office in two regency. Sometimes local data give more detail information especially location and time of accident. Furthermore, primary data like road geometric, topography, type of pavement, width and length of road segment, number of traffic, and some interviews should be directly done in the field to capture situation and environment region.

\subsubsection{Data Analysis}

To analyze data from some inputs and sources as previous step, the data must be compiled for filtering them. This process is to choose or to discharge some data which contributing or not contributing in the analysis later on. Description method will be applied in analysis step because it is able to indicate the condition in the field.

\section{Results and Discussions}

\subsection{Description of Road Segment}

Based on data from field investigation as shown in some picture that mainly provincial road has a width of $4.5 \mathrm{~m}$ in average and smooth surface with asphaltic pavement but several spot of segments in poor condition.

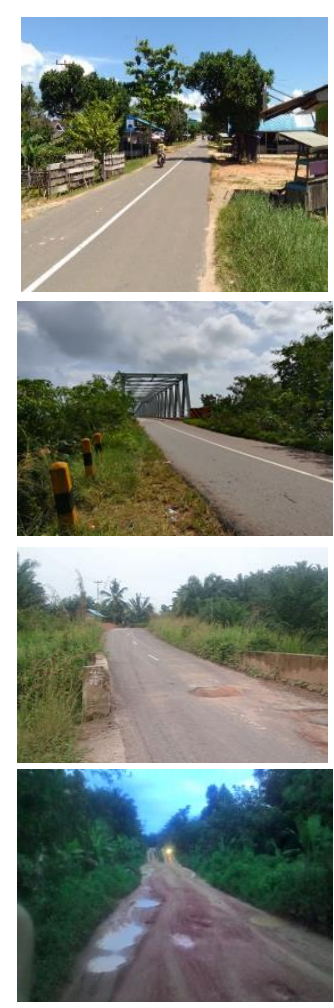

KM 50 segment Teluk Batang to Siduk (total $68 \mathrm{~km}$ )

KM 30 segment Ketapang to Kendawangan (total $86.5 \mathrm{~km}$ )

KM 40 segment Simpang Pelang to Batu Tajam (total $64.5 \mathrm{~km}$ )

KM 80 segment Nanga Tayap to Manis Mata $(160 \mathrm{~km})$

Figure 1 Condition of provincial road for 4 road segments

\subsection{Fatality}

As a comparison the number of the fatalities in Indonesia, West Kalimantan province, Pontianak as capital city of West Kalimantan province, respectively, as shown in the table below. 
Table 1. Comparison the number of fatalities

\begin{tabular}{lccl}
\hline $\begin{array}{l}\text { Location of } \\
\text { observation }\end{array}$ & $\begin{array}{c}\text { Fatality } \\
\text { (number of } \\
\text { accidents each } \\
100.000 \\
\text { inhabitant) }\end{array}$ & $\begin{array}{c}\text { Death } \\
\text { tolls a } \\
\text { year }\end{array}$ & $\begin{array}{l}\text { Populati } \\
\text { on } \\
\text { (million) }\end{array}$ \\
\hline $\begin{array}{l}\text { Indonesia } \\
\text { West Kalimantan }\end{array}$ & 12.0 & 30.000 & 250 \\
province & 7.75 & 372 & 4.80 \\
Capital of Pontianak & 12.0 & 72 & 0.60 \\
Location of study & 8.10 & 47 & 0.58 \\
\hline \multicolumn{2}{l}{ Source: Data Analysis from Provincial Report $[2,3]$}
\end{tabular}

Based on the table above that the fatality at the location of study is few higher than the fatality in province of West Kalimantan, though it is lower than the fatality in Indonesia and Capital of Pontianak. But it takes concerned that the fatality in capital city of Pontianak is so close to fatality in Indonesia.

\subsection{Type of Collision}

Generally, type of provincial road is two lane two way. Therefore, median to separate direction of traffic flow is unavailable. This condition has high possibility which frontal collision type between two differences of traffic flow direction as on Table 2 [3].

Table 2. Percentage of accident number to type of collision

\begin{tabular}{ccccc}
\hline Type of & \multicolumn{5}{c}{ Percentage of accident (\%) } \\
collision & Indonesia & $\begin{array}{c}\text { Prov. } \\
\text { Kalbar }\end{array}$ & $\begin{array}{c}\text { Pontianak } \\
\text { capital city }\end{array}$ & $\begin{array}{c}\text { Location } \\
\text { of study }\end{array}$ \\
\hline $\begin{array}{c}\text { Frontal } \\
\text { collision }\end{array}$ & 20.00 & 30.70 & 23.80 & 42.10 \\
Front-edge & 15.00 & 19.10 & 14.35 & 11.20 \\
Front-rear & 19.00 & 12.80 & 13.90 & 17.70 \\
$\begin{array}{c}\text { Crash into } \\
\text { Pedestrian }\end{array}$ & 15.00 & 13.10 & 11.00 & 12.60 \\
Single accident & 4.00 & 6.80 & 9.10 & 7.70 \\
\hline
\end{tabular}

Table 2 above shows that frontal collision type has the highest percentage (42.1\%). It is accordance with assumption that frontal accident on two-lane two-way road has high possibility. Even the proportion of this type is highest compared to three locations namely in Indonesia, West Kalimantan (Kalbar) province and Capital city of Kalbar province. It means that number of accidents with frontal collision type at the location of study need to be tackled in order to reduce that number. Other useful information from the table above that pedestrians become victim with percentage range from 11 to $15 \%$.

\subsection{Collision based on vehicle type}

In the West Kalimantan province, the composition of motor cycle is around 90\% [2]. It is really normal when percentage of motor cycle involved into accident is also dominated by type of motor cycle.

Table 3. Percentage based on vehicle type

\begin{tabular}{|c|c|c|c|c|}
\hline \multirow[b]{2}{*}{$\begin{array}{l}\text { Vehicle } \\
\text { type }\end{array}$} & \multicolumn{4}{|c|}{ Percentage of vehicle type $(\%)$} \\
\hline & Indonesia & $\begin{array}{l}\text { Prov. } \\
\text { Kalbar }\end{array}$ & $\begin{array}{c}\text { Pontianak } \\
\text { capital } \\
\text { city }\end{array}$ & $\begin{array}{l}\text { Location } \\
\text { of study }\end{array}$ \\
\hline Motor cycle & 61.0 & 64.9 & 78.1 & 71.1 \\
\hline $\begin{array}{l}\text { Passenger } \\
\text { car }\end{array}$ & 7.0 & 11.5 & 11.1 & 10.0 \\
\hline Bus & NA & 6.7 & 0.7 & 0.68 \\
\hline $\begin{array}{c}\text { Goods } \\
\text { vehicle }\end{array}$ & NA & 16.1 & 9.6 & 17.3 \\
\hline $\begin{array}{l}\text { Particular } \\
\text { vehicle }\end{array}$ & NA & 0.8 & 0.44 & 0.85 \\
\hline
\end{tabular}

Percentage of motor cycle involved on an accident at the location study is really high. It is bigger compared to the percentage in Indonesia and Kalbar province. Unfortunately, the percentage of accident using motor cycle in Pontianak is highest. It must pay attention to do special effort.

\subsection{Factors influencing accident}

Generally, some factors that contribute an accident consist of human error, vehicle, road environment, and combination of them. The human error contributes around $67 \%$ of accident number. The vehicle condition and the road environment contribute $5 \%$ and $4 \%$ respectively. Combination of three factors give around 24\% [4]. Based on data analysis of this research indicate that the road environment gives $2.1 \%$ of accident number. The vehicle condition contributes $0.5 \%$. Meanwhile the human error contributes around $64.9 \%$ which $60.7 \%$ of accident because of disorderly behavior such as over-speed, overtaking on curving road crossing the marking of solid line.

\subsection{Probability of accident}

Ratio the number of accidents to the length of road segment can be considered to estimate a probability value when the road user ride on the road. The table below shows probability per kilometer for the road user when passing through the road segment, presented on Table 4. 
Table 4. Probability of an accident

\begin{tabular}{|c|c|c|c|c|}
\hline Link of the road & $\begin{array}{c}\text { Road } \\
\text { segment }\end{array}$ & $\begin{array}{l}\text { Length } \\
(\mathrm{km})\end{array}$ & $\begin{array}{c}\text { Acci- } \\
\text { dent } \\
\text { Number } \\
\text { (times) }\end{array}$ & $\begin{array}{c}\text { Acci- } \\
\text { dent } \\
\text { per km }\end{array}$ \\
\hline \multirow[t]{3}{*}{$\begin{array}{l}\text { Teluk Batang- } \\
\text { Siduk }\end{array}$} & & 67.0 & 20 & 0.2985 \\
\hline & $\begin{array}{l}\text { Tlk. Batang } \\
\text { - Sukadana }\end{array}$ & 47.0 & 12 & 0.2553 \\
\hline & $\begin{array}{l}\text { Sukadana - } \\
\text { Sp. Siduk }\end{array}$ & 21.0 & 8 & 0.3809 \\
\hline \multirow[t]{3}{*}{$\begin{array}{ll}\text { 2. } & \text { Ketapang- } \\
\text { Kendawangan }\end{array}$} & & 86.5 & 21 & 0.2427 \\
\hline & $\begin{array}{l}\text { Ketapang- } \\
\text { Pesaguan }\end{array}$ & 21.5 & 19 & 0.8837 \\
\hline & $\begin{array}{l}\text { Pesaguan- } \\
\text { Kenda- } \\
\text { wangan }\end{array}$ & 65.0 & 2 & 0.0307 \\
\hline \multirow[t]{6}{*}{$\begin{array}{l}\text { Na.Tayap- } \\
\text { Manis Mata }\end{array}$} & & 160.3 & 10 & 0.0623 \\
\hline & $\begin{array}{c}\text { Na.Tayap - } \\
\text { Tumbang } \\
\text { Titi } \\
\text { Tumbang }\end{array}$ & 36.5 & 8 & 0.2191 \\
\hline & $\begin{array}{l}\text { Titi - } \\
\text { Tanjung }\end{array}$ & 32.0 & 1 & 0.0312 \\
\hline & $\begin{array}{l}\text { Tanjung- } \\
\text { Marau }\end{array}$ & 21.8 & 0 & NA \\
\hline & $\begin{array}{l}\text { Marau-Air } \\
\text { Upas }\end{array}$ & 21.0 & 0 & NA \\
\hline & $\begin{array}{l}\text { Air Upas- } \\
\text { Manis Mata }\end{array}$ & 49.0 & 1 & 0.0204 \\
\hline $\begin{array}{ll}\text { 4. } & \text { Sp.Pelang- } \\
\text { Batu Tajam }\end{array}$ & & 64.5 & 0 & NA \\
\hline
\end{tabular}

Table 4 above shows that link of Ketapang to Kendawangan on segment Ketapang to Pesaguan has highest possibility around 0.884 per $\mathrm{km}$. Furthermore, some effort must be focused on the segment to reduce number of accident and simultaneously reduce probability accident.

\section{Conclusion}

Based on the investigation in this study, the accident prone at some location of the provincial road generally two lane two way which width is narrow around $4.5 \mathrm{~m}$. Fatality at the location study is low compared to national fatality. Also, the frontal collision takes a bigger portion on type of two lane two way. Motor cycles involved on an accident dominates or take big portion. The accident may cause by the human error dominates with percentage of more than $65 \%$. The probability number of accidents that located in segment of Ketapang to Pesaguan around 0.884 each kilometer of road length.

\section{Acknowledgement}

This research is joint funded of DIPA by Fakultas Teknik Universitas Tanjungpura and supported by Dinas Perhubungan Provinsi West Kalimantan (Kalbar). Author would like to thank Mr. Ade Elbani and Mr. Amin that provided helpful some suggestions for this work.

\section{References}

[1] Murjanto, D (2012), "Rekayasa Keselamatan Jalan", Kementerian PU, Indonesia

[2] Pitono (2018), "Kalimantan Barat Dalam Angka 2018", Biro Pusat Statistik, Pontianak

[3] Annual Report (2017), "Data Kecelakaan di Provinci Kalimantan Barat".

[4] Suhardi (2012), "Implementasi Program Keselamatan Jalan", Masyarakat Transportasi Indonesia, Jakarta

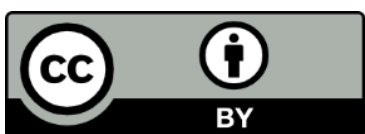

This is an open-access article distributed under the terms of the Creative Commons Attribution 4.0 International License (CC-BY). 